\title{
A FUZZY BASED PV FED BRUSHLESS DC MOTOR
}

\author{
Vinay $\mathbf{P}^{1}$, Manju Ann Mathew ${ }^{2}$ \\ ${ }^{1}$ M.Tech Scholar, Department of EEE, Mar Baselios College of Engineering \& Technology, Kerala, India \\ ${ }^{2}$ Assistant Professor, Department of EEE, Mar Baselios College of Engineering \& Technology, Kerala, India
}

\begin{abstract}
Renewable energy sources have now become common much more owing to its necessity rather than effectiveness. Of the various renewable energy sources, Solar Photovoltaic is one among the cheapest and widely used. Maximum Power Point Techniques are used to extract the maximum power from a PV module and the fuzzy based MPPT technique has been found to provide better results for randomly varying atmospheric conditions as compared to other methods. Induction Motors have been in use for years and now are being replaced by Brushless DC Motors owing to their advantages. The main advantages being a higher efficiency and noiseless operation. For the effective regulation of MPPT, we make use of DC-DC converters. Sepic converters has found to extract more power as compared to other buck - boost converters such as Cuk or fly back. In this work, a Fuzzy based MPPT uses a Sepic converter which drives a BLDC motor.
\end{abstract}

Keywords: Solar PV, Maximum Power Point Tracking, Sepic Converter, Brushless DC Motor

\section{INTRODUCTION}

Solar Photovoltaic have gained prominence over the years since it is pollution free, world wide availability etc. But the fact is that it is required to meet the needs of the current power requirements. The modelling of PV modules have been done in various literatures [1]. For extracting the power from a PV module, we make use of Maximum Power Point Tracking algorithms. The heart of any MPPT technique is a DC - DC converter which regulates the source impedance which varies with atmospheric conditions and the converter duty ratio is changed to match the load impedance so that maximum power transfer occurs [2]. Of the various available Buck boost configurations, a Single Ended Primary Inductor Converter (SEPIC) has found to possess several advantages over other configurations such as Cuk, Flyback, and Zeta etc. The main and notable advantage being that of a non-inverted output.

The advancement of power electronics and evolution of control techniques enabled the use of Induction motors for most of the Industrial applications. But now, Induction motors are being replaced by BLDC motors which have a higher efficiency as compared to Induction motors, high Speed Torque characteristics and reduced size of machine etc. A BLDC motor can infact be considered as a DC motor which runs on $\mathrm{AC}$ power. In order to drive BLDC motors, we have to use an inverter whose gate pulse are generally created from the hall voltage of the motor extracted with Hall Effect sensors.

In this work, a PV system with varying environmental conditions are considered and for such conditions we require MPPT techniques. A Fuzzy based MPPT system has proven to extract much more power with low settling time and little dynamic response. In fact a sepic converter can a little more power as compared to Cuk converter. A BLDC motor is driven through an inverter interface. The overall block diagram is shown in figure 1.

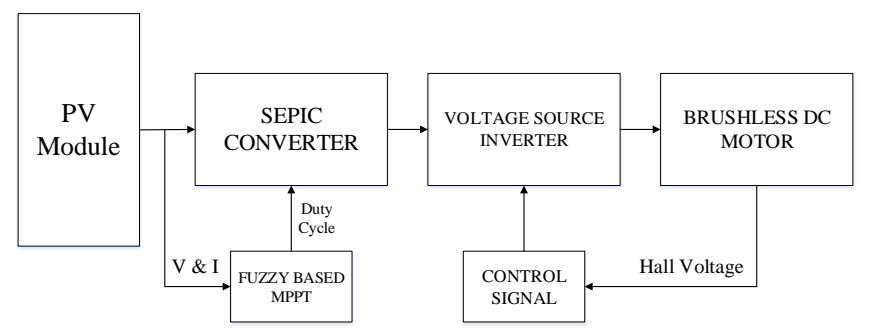

Fig -1: Block Diagram of the Overall System

The hall sensor provides the required control strategy for driving the inverter. The speed is fed back to the inverter to make it a constant speed variable load motor.

The first part of the paper deals with the modelling and simulation of PV module. The modelling of the system based on MatlablSimulink has been proposed in many papers. The next is the modelling of the Fuzzy based MPPT and is followed by the sepic converter fed BLDC motor simulation and analysis of the motor parameters are done.

\section{MODELLING OF PV MODULE}

A photovoltaic cell is one which converts incoming sunlight into electric current by means of photoelectric effect. It is basically a p-n junction fabricated in a wafer. The output of a PV cell is very low and hence these cells are connected in series and parallel to increase the voltage and current levels. 
Since a PV cell exhibits nonlinear relation between voltage and current for varying levels of temperature and Irradiance levels. A solar cell can be modelled by using a one diode model, which is the most widely used method. We can also a two diode model or a three diode model for modelling a PV cell. In this work, a single diode mode is considered. In a sone diode model, a PV cell is modelled as a variable current source in anti-parallel with a diode, also a series and shunt resistance $\left(R_{S} \& R_{P}\right)[4]$.

The one diode model is shown in figure 2 .

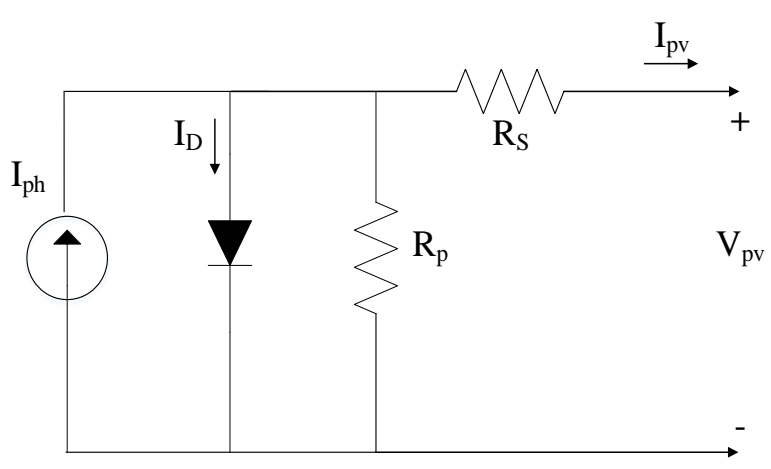

Fig -2: One Diode Equivalent circuit of PV cell

The output of PV cell is given by

$I=N_{\mathrm{p}} I_{\mathrm{ph}}-N_{\mathrm{p}} I_{\mathrm{o}}\left(\exp \left[\frac{\mathrm{q}(\mathrm{V} / \mathrm{Ns}+\mathrm{IRs} / \mathrm{Np})}{\mathrm{AkT}}\right]-1\right)-\frac{V}{K_{\mathrm{p}}}(1)$

where, $I$ is the current, $V$ is the voltage of the PV module, $I p h$ is the photo-current, $I_{0}$ is the reverse saturation current, $N p$ is the number of cells connected in parallel, $N s$ is the number of cells connected in series, $q$ is the charge of an electron $\left(1.6^{*} 10^{-19} \mathrm{C}\right), k$ is Boltzmann's constant $\left(1.38^{*} 10-23 \mathrm{~J} / \mathrm{K}\right), A$ is $p$ - $n$ junction ideality factor, $(1<a<2, a=1$ being the ideal value), and $T$ is the PV module temperature.

For a solar cell, the only generated current is by means of a photo current which is directly dependent on temperature as well as irradiance level given by

$$
I_{\mathrm{ph}}=\left[I_{\mathrm{sc}}+k_{1}\left(T-T_{\mathrm{ref}}\right)\right] G
$$

where $\mathrm{I}_{\mathrm{sc}}$ is the short circuit current of the PV cell, $\mathrm{K}_{1}$ is the short-circuit current/temperature coefficient $\mathrm{T}$ is the present atmospheric temperature and $\mathrm{T}_{\text {ref }}$ is the temperature at nominal condition $\left(250^{\circ} \mathrm{C}\right.$ and $\left.1000 \mathrm{~W} / \mathrm{m}^{2}\right), \mathrm{G}$ is the present irradiance level.

The P-V and I-V characteristics of a PV cell are shown in figure 3. The maximum power is attained when the cell operates at $\mathrm{I}_{\mathrm{mp}}$ and $\mathrm{V}_{\mathrm{mp}}$.

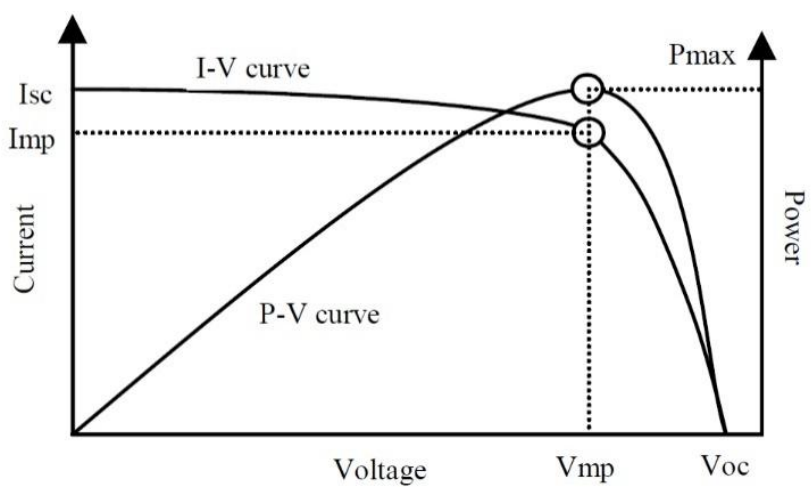

Fig -3: Current-voltage and power-voltage characteristics of a solar cell

The PV module considered for simulation was Tata TP 250 Series with specifications at Nominal Operating Cell Temperature (NOCT $-20^{\circ} \mathrm{C} \& 800 \mathrm{~W} / \mathrm{m}^{2}$ ) was considered rather than Standard Test Condition (STC $-25^{\circ} \mathrm{C} \&$ $\left.1000 \mathrm{~W} / \mathrm{m}^{2}\right)$.

The electrical parameters of the TP 250 series PV module is as shown in Table 1.

Table -1: PV Module Parameters

\begin{tabular}{|l|l|}
\hline Electrical Parameters & Value \\
\hline Maximum Power $\left(\mathrm{P}_{\max }\right)$ & 180 \\
\hline Voltage at $\mathrm{P}_{\max }\left(\mathrm{V}_{\mathrm{mp}}\right)$ & 26.7 \\
\hline Current at $\mathrm{P}_{\max }\left(\mathrm{I}_{\mathrm{mp}}\right)$ & 6.74 \\
\hline Open Circuit Voltage $\left(\mathrm{V}_{\mathrm{oc}}\right)$ & 32.8 \\
\hline Short Circuit Current $\left(\mathrm{I}_{\mathrm{sc}}\right)$ & 7.35 \\
\hline Number of Series Cells $\left(\mathrm{N}_{\mathrm{s}}\right)$ & 60 \\
\hline Number of Parallel Cells $(\mathrm{Np})$ & 1 \\
\hline
\end{tabular}

The simulated PV module is shown in figure 3.

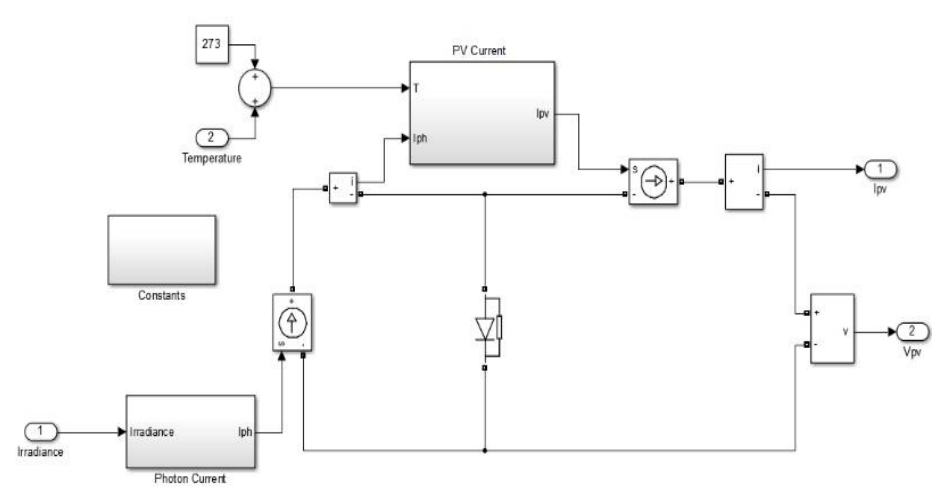

Fig -4: PV module model 


\section{FUZZY BASED MPPT TECHNIQUE}

Maximum Power Point Tracking algorithms are used to find the optimum point of voltage and current at which the maximum power can be extracted from a PV module. There are several MPPT techniques ranging from simple to complex and very complex. The simple MPPT techniques includes the Perturb and Observe method (P\&O) and Incremental Conductance Method (ICM) [3]. The Fuzzy based MPPT technique has become common due to the advent of DSP, FPGA etc. Also, the fuzzy based system have found to extract much more power compared some of the commonly used techniques. The main advantages of a fuzzy based system is that it offers a better performance, robust and also it doesn't require the knowledge of the exact system to act upon. The Fuzzy Logic Control consist of Fuzzification, Inference (Rule Base) and Defuzzification as shown in figure 5.

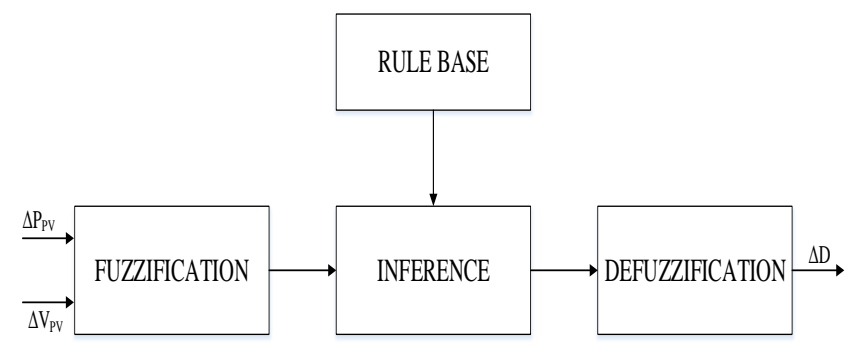

Fig -5: Fuzzy Logic Controller

During the Fuzzification process, the input variables are transformed into a linguistic variable based on crisp sets of membership function. The number of membership functions used depends on the accuracy of the controller, but it usually varies between 5 and 7 . The seven fuzzy levels used are namely - NB (Negative Big), NM (Negative Medium), NS (Negative Small), NZ (Negative Zero), ZE (Zero), PZ (Positive Zero), PS (Positive Small), PM (Positive Medium) and PB (Positive Big) [5]. In most of the works, the fuzzy based MPPT has two inputs and one output. The two inputs being Error and change in error given by

$$
\begin{gathered}
E(k)=\frac{\Delta I}{\Delta V}+\frac{I}{V} \\
\Delta E(k)=E(k)-E(k-1)
\end{gathered}
$$

where, $I$ is output current from PV array; $V$ is output voltage from array, $\Delta I=I(k)-I(k-1)$, and $\Delta V=V(k)-$ $V(k-1)$.

The Membership Functions used are shown in figure 6.

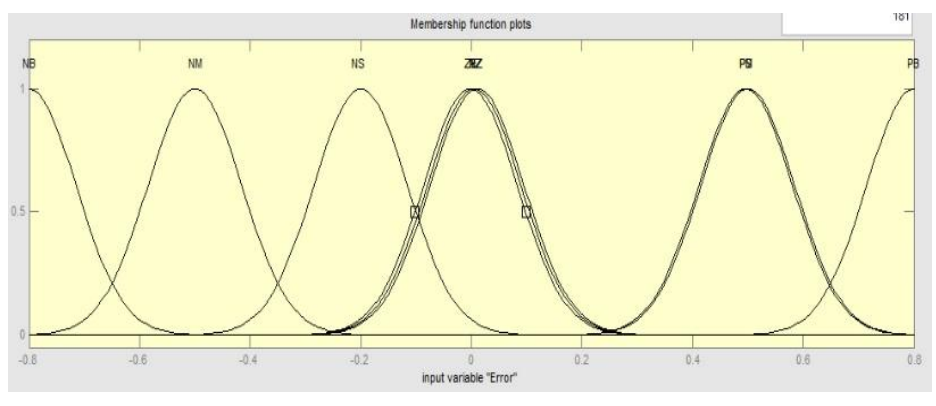

(a)

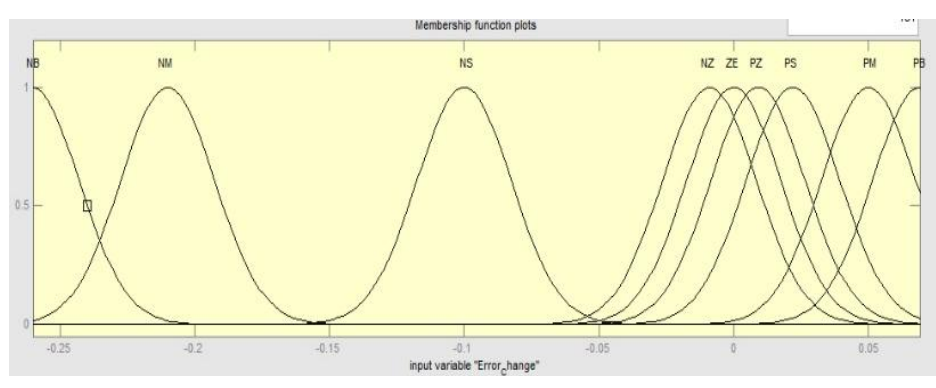

(b)

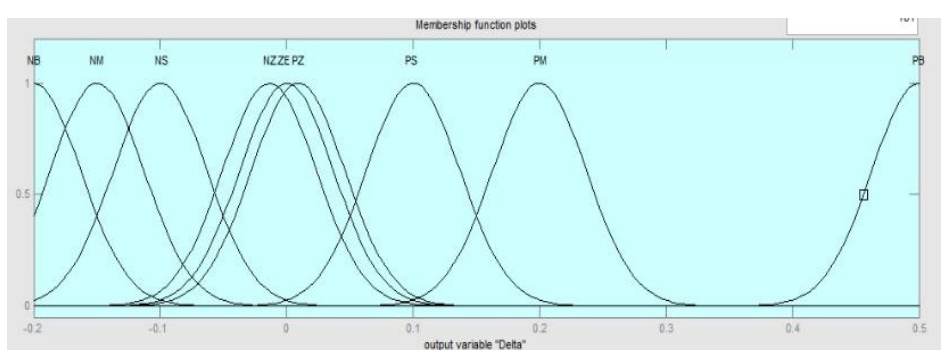

(c)

Fig -6 Fuzzy Membership Function

(a) Input - Error (b) Input - Error Change (c) Output- Delta D The output of the fuzzy logic converter is usually a change in the duty ratio of the power converter, $\Delta D$, or a change in the reference voltage of the DC-link, $\Delta V$. The rule base, also known as rule base lookup table or fuzzy rule algorithm, associates the fuzzy output to the fuzzy inputs based on the power converter used. The advantages of these controllers, besides dealing with imprecise inputs, not needing an accurate mathematical model and handling nonlinearity, are fast convergence and minimal oscillations around the MPP. Furthermore, they have been shown to perform well under step changes in the irradiation.

Next comes the inference part, which can be carried out using many of the available methods - Mamdani's method is the most widely used technique. The Final stage is the defuzzification, which is done using the centroid method produces the Output which is the required duty cycle. 


\section{SEPIC CONVERTER}

The heart of any MPPT system is a DC - DC converter, it is because it is the converter duty ratio that matches the varying source impedence of PV panel in order to attain the maximum power. Almost any DC - DC converter can be used, for this work a SEPIC converter is being used. A Sepic converter has been found to extract somewhat more power compared to other methods. Also the input current ripple while used for MPPT applications have been found low for a Sepic converter. A Sepic converter driving a constant load is shown in figure 7.

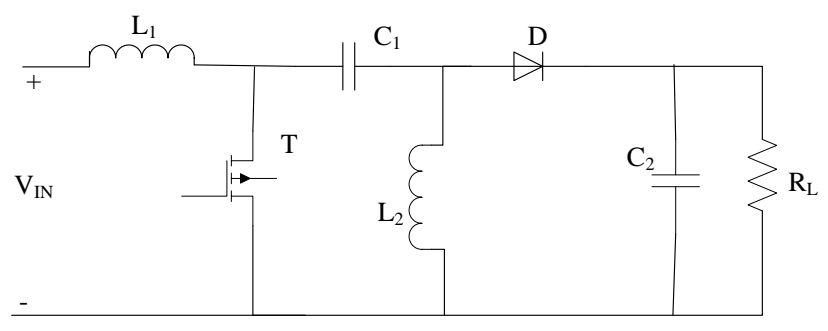

Fig -7 SEPIC Converter

The output voltage and current are given by

$$
\begin{aligned}
& \frac{V_{\mathrm{O}}}{V_{\mathrm{i}}}=\frac{D}{1-D} \\
& \frac{I_{\mathrm{O}}}{I_{\mathrm{S}}}=\frac{1-D}{D}
\end{aligned}
$$

The design equations are given by

$$
\begin{gathered}
L_{1}, L_{2}=\frac{V_{\mathrm{dc}} D}{\Delta I_{1} f} \\
C_{1}=\frac{I_{0}(D)}{\Delta V_{\mathrm{C} 1} f} \\
C_{2}=\frac{I_{\mathrm{O}}(D)}{0.5 \Delta V_{\mathrm{C} 2} f}
\end{gathered}
$$

\section{BRUSHLESS DC MOTOR}

Brushless DC motors have higher power density due to lack of copper losses as they do not require mechanical commutation mechanisms which results in compact and robust structures. A BLDC motor is a synchronous motor that uses a rotor position sensor and inverter to control the armature currents. Usually BLDC motors are used where efficiency is a cause of concern or where the spikes created by commutators re to be avoided. There are mainly two types of BLDC motors - Trapezoidal type and Sinusoidal type. For Trapezoidal type, the back emf is trapezoidal in shape and their phases are supplied with quasi square wave for ripple free torque operation. On the other hand, the sinusoidal type requires a sinusoidal phase currents.
The commutation process of a BLDC motor are performed by an inverter and a rotor position sensor [6].

The electronic commutator generates the switching pulse for the voltage source inverter. The rotor position are sensed by the hall effect sensor and emf signals are generated. These emf signals are decoded to get the respective switching signals as shown in Table 1 [7].

Table -1: Switching Signals based on Hall Effect sensor

\begin{tabular}{|l|l|l|l|l|l|l|l|l|}
\hline \multicolumn{7}{|c|}{ Hall Signals } & \multicolumn{7}{|l|}{ Switching Signals } \\
\hline $\mathrm{H}_{\mathrm{a}}$ & $\mathrm{H}_{\mathrm{b}}$ & $\mathrm{H}_{\mathrm{c}}$ & $\mathrm{S}_{1}$ & $\mathrm{~S}_{2}$ & $\mathrm{~S}_{3}$ & $\mathrm{~S}_{4}$ & $\mathrm{~S}_{5}$ & $\mathrm{~S}_{6}$ \\
\hline 0 & 0 & 0 & 0 & 0 & 0 & 0 & 0 & 0 \\
\hline 0 & 0 & 1 & 0 & 0 & 0 & 1 & 1 & 0 \\
\hline 0 & 1 & 0 & 0 & 1 & 1 & 0 & 0 & 0 \\
\hline 0 & 1 & 1 & 0 & 1 & 0 & 0 & 1 & 0 \\
\hline 1 & 0 & 0 & 1 & 0 & 0 & 0 & 0 & 1 \\
\hline 1 & 0 & 1 & 1 & 0 & 0 & 1 & 0 & 0 \\
\hline 1 & 1 & 0 & 0 & 0 & 1 & 0 & 0 & 1 \\
\hline 1 & 1 & 1 & 0 & 0 & 0 & 0 & 0 & 0 \\
\hline
\end{tabular}

A BLDC motor can be analysed by using the following

$$
\begin{aligned}
{\left[\begin{array}{l}
V_{\mathrm{a}} \\
V_{\mathrm{b}} \\
V_{\mathrm{c}}
\end{array}\right]=\left[\begin{array}{lll}
R & 0 & 0 \\
0 & R & 0 \\
0 & 0 & R
\end{array}\right]\left[\begin{array}{c}
i_{\mathrm{a}} \\
i_{\mathrm{b}} \\
i_{\mathrm{c}}
\end{array}\right]+\left[\begin{array}{ccc}
L-M & 0 & 0 \\
0 & L-M & 0 \\
0 & 0 & L-M
\end{array}\right] p\left[\begin{array}{c}
i_{\mathrm{a}} \\
i_{\mathrm{b}} \\
i_{\mathrm{c}}
\end{array}\right] } \\
+\left[\begin{array}{l}
e_{\mathrm{a}} \\
e_{\mathrm{c}}
\end{array}\right]
\end{aligned}
$$

where $\mathrm{L}$ is the self-inductance of each phase, $\mathrm{M}$ is the mutual inductance between any two phases $\mathrm{V}_{\mathrm{a}}, \mathrm{V}_{\mathrm{b}}, \mathrm{V}_{\mathrm{c}}$ are the phase voltages, $i_{a}, i_{b}, i_{c}$ are the phase currents $e_{a}, e_{b}, e_{c}$ are the back emf signals of BLDC motor and $p$ is the differential operator.

The dynamic equations for mutual inductance

$$
\begin{aligned}
& V_{\mathrm{a}}=R i_{\mathrm{a}}+L \frac{d}{d t}\left(i_{\mathrm{a}}\right)+e_{\mathrm{a}} \\
& V_{\mathrm{b}}=R i_{\mathrm{b}}+L \frac{d}{d t}\left(i_{\mathrm{b}}\right)+e_{\mathrm{b}} \\
& V_{\mathrm{c}}=R i_{\mathrm{c}}+L \frac{d}{d t}\left(i_{\mathrm{c}}\right)+e_{\mathrm{c}}
\end{aligned}
$$

The electromagnetic torque is given by

$$
T_{\mathrm{e}}=\frac{1}{\omega}\left(e_{\mathrm{a}} i_{\mathrm{a}}+e_{\mathrm{b}} i_{\mathrm{b}}+e_{\mathrm{c}} i_{\mathrm{c}}\right)
$$

The mechanical torque is given by

$$
T_{\mathrm{m}}=J \frac{d \omega}{d t}+B \omega+T_{\mathrm{L}}
$$


Where $\mathbf{J}$ is the moment of inertia of drive, B is the damping constant, $T_{L}$ is the load torque and $\omega$ is the rotor speed.

The relation between torque and speed is given by

$$
T_{\mathrm{L}} \propto \omega^{2}
$$

The three phase BLDC motor is primarily operated on a two phase basis, i.e.: the two phases which has the highest torque sensed by the rotor position are operated. The signals from the rotor position sensor generate a three digit number which varies for a $60^{\circ}$ as shown in figure 8 . It also features ideal current and back emf waveforms. Each time interval starts when stator and rotor field lines are $120^{\circ}$ apart and end when they are $60^{\circ}$ apart [8].

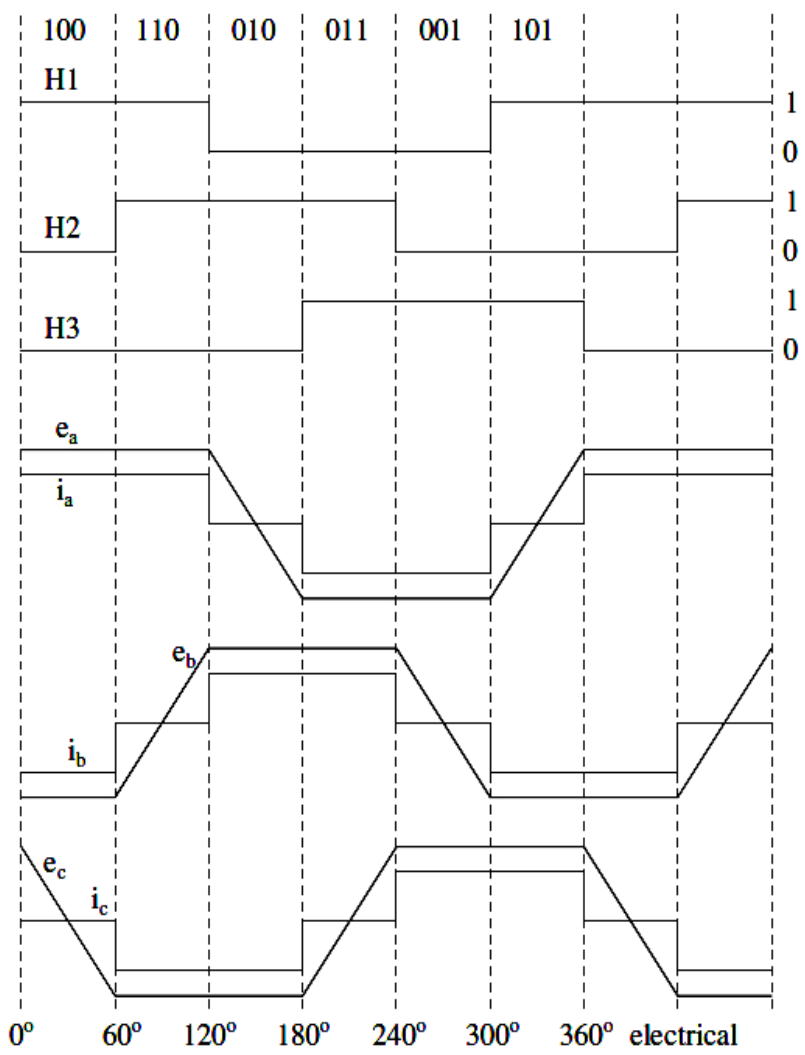

Fig -8 Back-emf's, phase currents and position sensor signals

The electrical motor parameters are shown in table 2.

Table -2: Motor Specifications

\begin{tabular}{|l|l|}
\hline Parameter & Value \\
\hline Armature Inductance $\left(\mathrm{L}_{\mathrm{a}}\right)$ & $8.5 \mathrm{mH}$ \\
\hline Armature Resistance $\left(\mathrm{R}_{\mathrm{a}}\right)$ & $2.875 \Omega$ \\
\hline Rotor Inertia $(\mathrm{J})$ & $0.8 \mathrm{e}-3 \mathrm{Kgm}{ }^{2}$ \\
\hline Damping constant $(\mathrm{B})$ & $1 \mathrm{e}-3 \mathrm{~N} \cdot \mathrm{m} . \mathrm{s} / \mathrm{rad}$ \\
\hline Back EMF constant $\left(\mathrm{k}_{\mathrm{b}}\right)$ & $0.175 \mathrm{~V} . \mathrm{Sec}$ \\
\hline
\end{tabular}

\section{MODELLING AND SIMULATION}

The simulations were carried out in Matlab ${ }^{\mathrm{TM}} / \mathrm{Simulink}^{\mathrm{TM}}$. The temperature and Irradiance level are provided on the basis of historically available data and hence it is a variable environmental condition [9]. The simulation of the fuzzy logic controller is shown in figure 9.

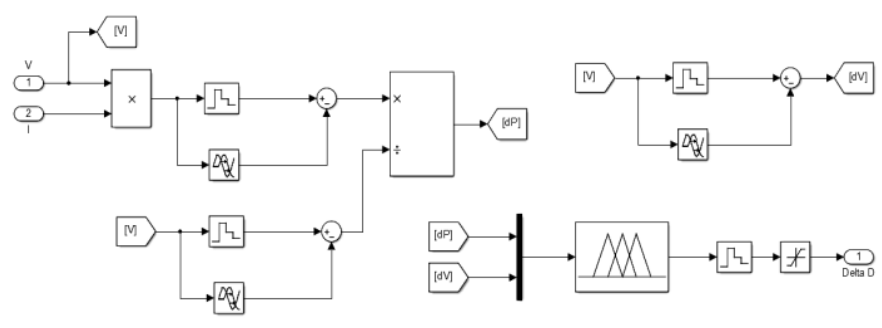

Fig -9 Simulation of FLC

The fuzzy based MPPT technique was found to possess much more efficiency for the provided Irradiance and Temperature levels. Also a Sepic converter was effective during comparison with an ordinary Buck-Boost converter and a Cuk converter. The Simulation diagram of a Sepic converter is shown in figure 10. The overall circuit simulation is featured in figure 11 .

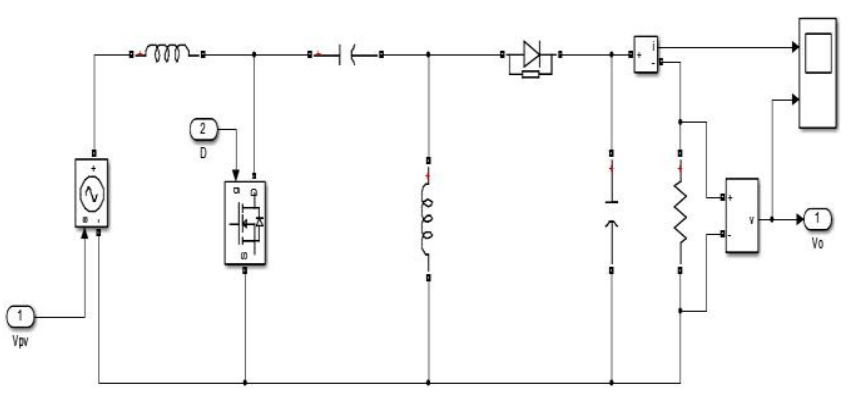

Fig -10 Sepic Converter

The converter simulation was done for an initial duty ratio of 0.5 . The fuzzy based system was able to extract about $230 \mathrm{~W}$ from a $250 \mathrm{~W}$ PV panel which was used for the motor drive.

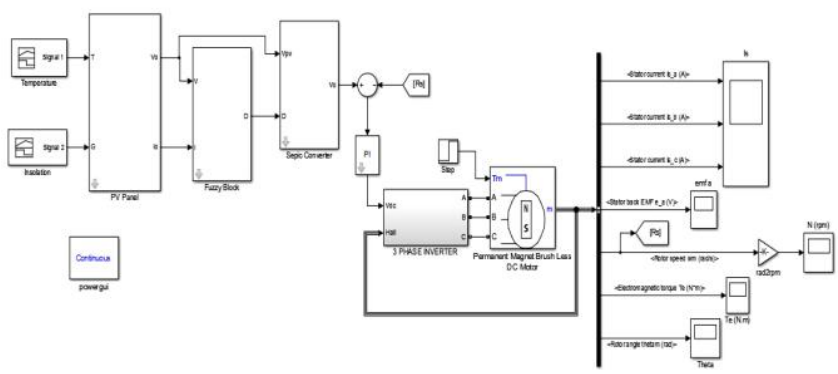

Fig -11 Overall Simulation Diagram 
The switching signals generated from hall voltages sensed from rotor position sensors are shown in figure 12. With the generated switching signal, the motor can be driven as a constant speed variable load motor.

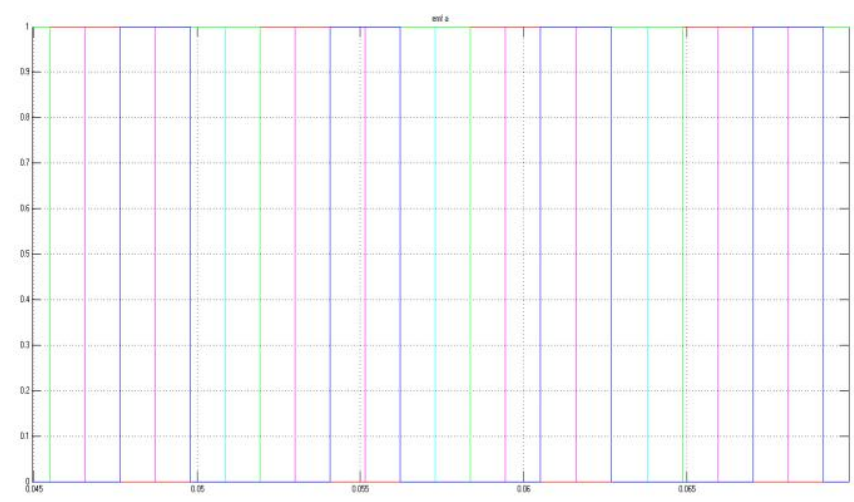

Fig -11 Switching signals

The three phase stator currents are shown in figure 12.

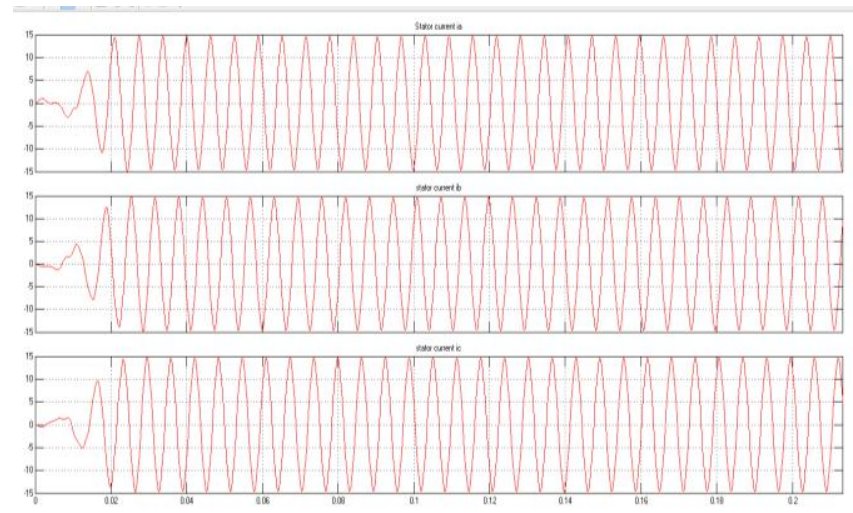

Fig -12 Stator current of BLDC motor

The stator back emf as required for a trapezoidal motor are trapezoidal in shape. The stator emf of phase is shown in figure 13.

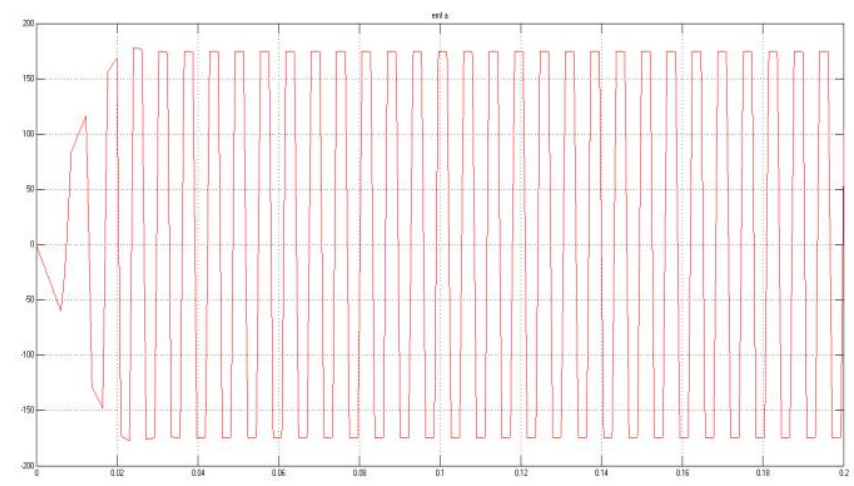

The electromagnetic torque and rotor speed are shown in figure 14 and 15 respectively. From the torque curve we can infer that the PV module was not able to drive the motor constantly without fluctuations.

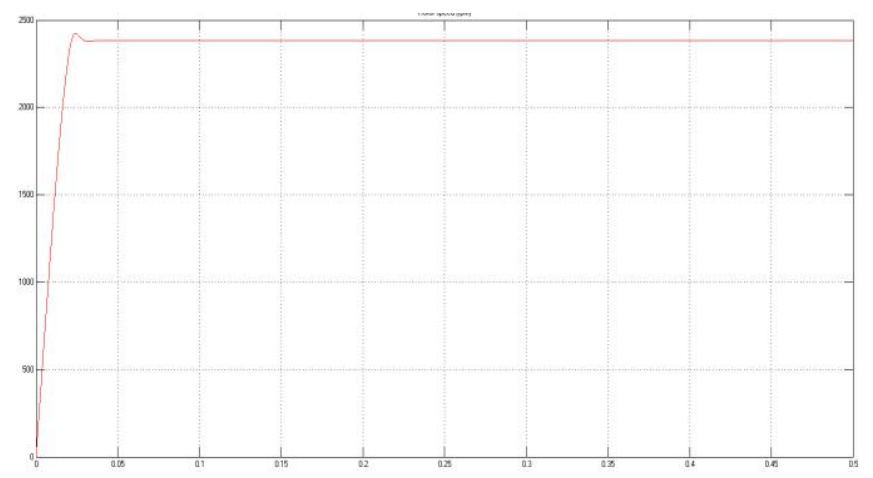

Fig -14 Rotor Speed of BLDC motor

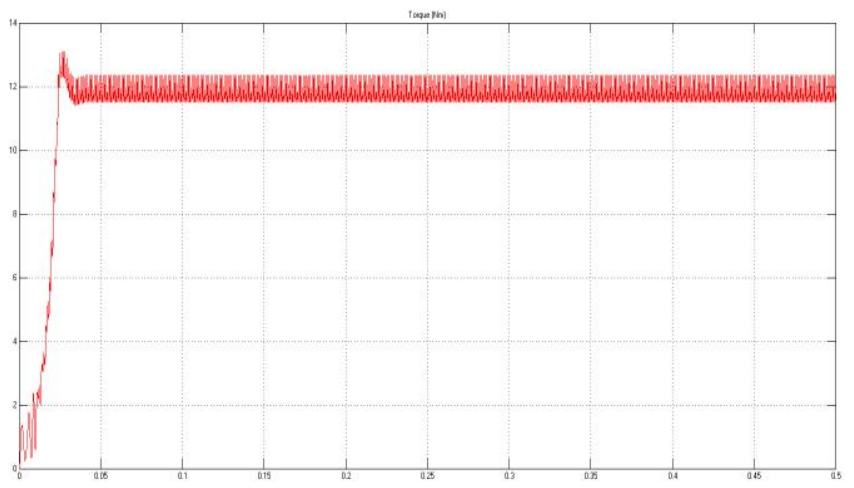

Fig -15 Electromagnetic torque

\section{CONCLUSIONS}

The simulation of a PV based Brushless DC Motor was done. In order to extract the maximum possible power from the PV module, a Fuzzy based MPPT technique along with a Sepic converter was modelled and evaluated. The BLDC motor was driven by a Voltage source Inverter with switching signals generated by the Hall Effect sensors. The overall system was found to behave similar to any normal operation of the motor. The simulation was done for a constant torque, the motor operated at constant speed, but the torque generated seemed to fluctuate more than usual. This may be due to the inability of the PV module to deliver the required power at every instant. So by using a PV system that can drive a BLDC motor with an excess of about $20 \%$ of the connected load. Still the current simulated system will be able to act as a constant speed motor. The only mode of powering remote areas for applications such as pumping, grinding rtc can be achieved by solar power, so it is better to use a BLDC motor instead of using Induction motor owing to their losses.

Fig -13 Back emf of phase A 


\section{REFERENCES}

[1] Marcelo G, Gazoli J. and Filho E., "Comprehensive Approach to Modeling and Simulation of Photovoltaic Arrays", IEEE Transactions on Power Electronics, Vol. 24, No. 5, May 2009, pp. 1198-1208.

[2] Esram T. and Chapman P., "Comparison of Photovoltaic Array Maximum Power Point Tracking Techniques", IEEE Transactions on Energy Conversion, Vol. 22, No. 2, June 2007, pp. 439-449.

[3] Subudhi B. and Pradhan R., "A comparative study on maximum powerpoint tracking techniques for photovoltaic power systems", IEEE Transactions on Sustainable Energy, vol. 4, no. 1, January 2013, pp. 8998.

[4] Gow, J.A. and Manning, C.D. "Development of a photovoltaic array model for use in power-electronics simulation studies," IEEE Proceedings on Electric Power Applications, Volume:146 , Issue: 2, pp. 193 200, March 1999.

[5] Ahmed M. Othman, Mahdi M.M. El-arini, Ahmed Ghitas, Ahmed Fathy, "Realworld maximum power point tracking simulation of PV system based on Fuzzy Logic control," NRIAG Journal of Astronomy and Geophysics, January 2014, 186-194.

[6] R. Feyzi, S. A. KH. Mozaffari Niapour, S. Danyali, M. Shafiei, "Supplying a Brushless DC Motor by Z-Source PV Power Inverter with FLC-IC MPPT by DTC Drive" Proceedings of the IEEE International Conference on Electrical Machines and Systems, October,2010,pp.694 $-699$

[7] Sreedevi S Nair, Mini Rajeev "Design and Simulation of PV Powered PMBLDC Motor for Water Pumping" Proceedings of Third Biennial National Conference, NCNTE, February, 2012.pp.65-70

[8] S. A. K. Mozafari Niapoor, S. Danyali, M. B. B. Sharifian, "PV Power System Based MPPT Z-Source Inverter to Supply a Sensorless BLDC Motor," IEEE Power Electronics \& Drive Systems \& Technologies Conference (PEDSTC), February, 2010,pp.111-116.

[9] Neena Sugathan, V. Biju, G Renuka, "Solar Activity and regional climate over short tome scales at Thiruvananthapuram, South Kerala, India," Indian Journal of Radio \& Space Physics, Vol 42, April 2013, pp 69-72.

\section{BIOGRAPHIES}

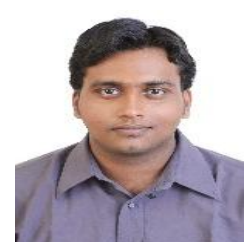

Vinay was born in Kerala in 1990. He completed his Bachelor Degree from University of Kerala. $\mathrm{He}$ is currently pursuing his Master's Degree in Power Control and Drives from University of Kerala. His area of interest includes Power Electronics, Drives and Renewable energy Sources. 